\author{
Тарасова О.В. \\ кандидат економічних наук, доцент \\ кафедра обліку та аудиту \\ Одеська національна академія харчових технологій \\ вул. Канатна, 112, м. Одеса, Україна, 65039 \\ E-mail: tarasovaelenaonaft@gmail.com \\ ORCID ID: 0000-0002-4372-3677
}

\title{
ПРОБЛЕМИ ФОРМУВАННЯ ДЕПОЗИТНОЇ БАЗИ КОМЕРЦІЙНИХ БАНКІВ УКРАЇНИ
}

У статті досліджуються проблеми формування банківських ресурсів, відновлення і нарощення депозитної бази комерційних банків, яка відіграє надзвичайно важливу роль у розвитку економіки. Обґрунтовано роль депозитного ринку у забезпеченні стабільного економічного зростання. Розглянуто сутність депозитних операцій та класифікацію депозитів за різними ознаками. Проаналізовано тенденції у формуванні депозитної бази комерційних банків України та диспропорції у сфері залучення банківських ресурсів. Основними проблемами банківської системи є скорочення вкладів населення, значна девальвація гривні, збитковість великої кількості банківських установ. Сформульовані завдання, вирішення яких дозволить оптимізувати депозитну політику банків, повернути довіру населення до банківських установ та стимулюватиме до заощаджень.

Ключові слова: депозит, депозитна операція, депозитна база, депозитна політика, заощадження, комерційний банк, економічне зростання.

This work is licensed under a Creative Commons Attribution 4.0 International License http://creativecommons.org/licenses/by/4.0/

Постановка проблеми та її зв'язок 3 важливими науковими та практичними завданнями. В умовах нестабільності фінансових ринків, збитковості підприємств, низького рівня доходів населення, масового банкрутства й ліквідації комерційних банків України виникає необхідність аналізу існуючих тенденцій формування депозитної бази банківських установ як головного джерела поповнення їх ресурсів. Без цього неможливе відновлення кредитування економіки та економічне зростання. В зв'язку з цим, актуальним $є$ питання відновлення депозитної бази банківської системи, визначення шляхів ії нарощення, заходів, які б повернули довіру населення до банківських установ та стимулювали до заощаджень.

Аналіз останніх публікацій 3 проблеми. Дослідження теоретичних та практичних аспектів функціонування банківської системи, в тому числі депозитних операцій банків, відображені в працях вітчизняних і зарубіжних вчених, серед яких: Г.I. Бірман, О.С. Врублевський, Н.I. Версаль, Н.О. Кожель, О.І. Лаврушин, В.Д. Лагутін, М.I. Савлук, B.М. Олійник, Й. Шумпетер та ін. Разом 3 цим, високо оцінюючи результати цих досліджень, слід констатувати, що проблеми формування депозитної бази банківських установ досліджені недостатньо.

Формулювання цілей дослідження. Метою статті є дослідження проблем формування банківських ресурсів, відновлення і нарощення депозитної бази комерційних банків.
Виклад основних результатів та їх обгрунтування. В сучасній економічній літературі, характеризуючи сутність депозитних операцій, вчені висловлюють різні думки. Так, О.С. Врублевський під депозитними операціями розуміє залучення грошових коштів або банківських металів від вкладників на їхні рахунки в банку на договірних засадах або депонування грошових коштів вкладниками 3 оформленням їх ощадними (депозитними) сертифікатами [1]. На думку Н.О. Кожель, до депозитних операцій банків слід віднести всі їхні операції щодо залучення заощаджень громадян, вільних коштів юридичних осіб, зокрема вкладення тимчасово вільних ресурсів одних банків в інші банки та в центральний банк [2]. В.Д. Лагутін вважає, що депозитні операції - це операції із залучення або розміщення коштів на депозит [3]. О.П. Орлюк відмічає, що депозитна операція - це договір між банком і клієнтом [4]. При цьому, слід відмітити, що більшість вчених визначають сутність депозитних операцій як зарахування коштів на депозит.

Депозитні операції належать до пасивних операцій комерційних банків. Відповідно до положення «Про порядок здійснення банками України вкладних (депозитних) операцій з юридичними і фізичними особами», затвердженого постановою Правління Національного банку України від 03.12.2003 року № 516, вкладна (депозитна) операція - операція банку із залучення грошових коштів або банківських металів від юридичних і фізичних осіб на вкладні 
(депозитні) рахунки в банку на договірних засадах або депонування грошових коштів вкладниками 3 оформленням їх ощадними (депозитними) сертифікатами [5].

Відповідно до Закону України «Про банки і банківську діяльність» вклад (депозит) - це кошти в готівковій або у безготівковій формі, у валюті України або в іноземній валюті, які розміщені клієнтами на їніх іменних рахунках у банку на договірних засадах на визначений строк зберігання або без зазначення такого строку і підлягають виплаті вкладнику відповідно до законодавства України та умов договору [6].

В умовах ринку для підтримки своєї конкуре- нтоспроможності банки повинні пропонувати своїм клієнтам усе нові послуги, використовувати нові фінансові інструменти, розробляти власну депозитну політику. Депозитна політика комерційного банку включає комплекс заходів із формування депозитного портфеля і визначення найефективнішої комбінації джерел.

Зростаюча конкуренція між комерційними банками за внески фізичних та юридичних осіб призводить до появи значної кількості різних депозитів. Класифікацію депозитів за категоріями вкладників, економічним змістом, строками, валютою та іншими ознаками наведено на рис. 1.

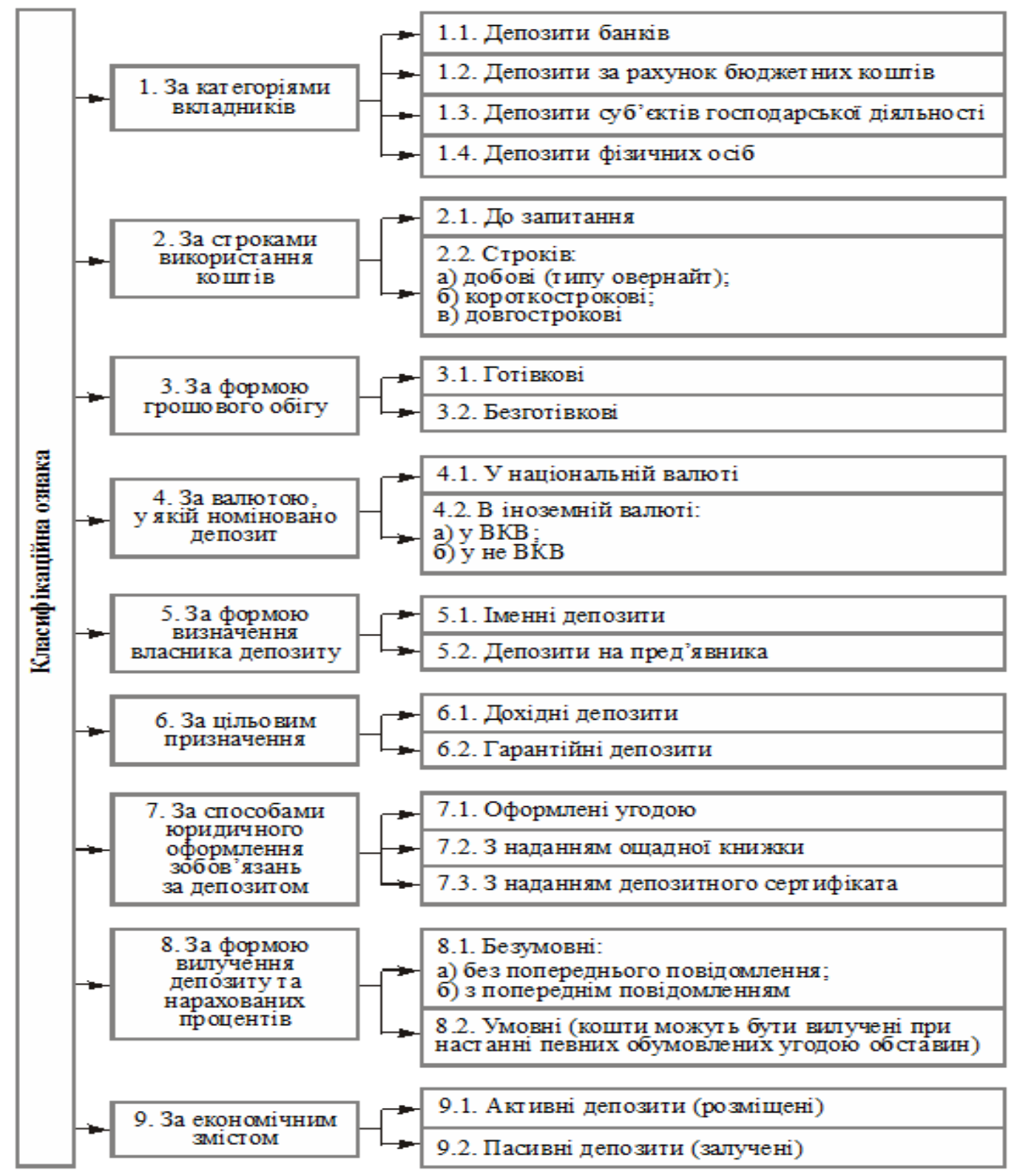

Рис. 1. Класифікація депозитів за різними ознаками [7]

У останні роки перед банківською системою України встала низка проблем, основними серед яких можна вважати: скорочення вкладів населення, погі- ршення якості кредитного портфелю, значну девальвацію гривні, високі темпи інфляції, збитковість значної кількості банківських установ тощо. 
Основну частину ресурсів банків сформовано за рахунок депозитів клієнтів. Відомості про пасиви, зобов’язання та депозитні кошти фізичних і юридич- них осіб банків України за останні 10 років наведено у табл. 1.

Таблиця 1

Пасиви, зобов'язання та депозитні кошти фізичних і юридичних осіб банків України у 2008-2018 рр., млн. грн.*

\begin{tabular}{|c|c|c|c|c|c|c|c|c|c|}
\hline \multirow{2}{*}{$\begin{array}{c}\text { Звітна дата } \\
1.01 .2008 \text { p. }\end{array}$} & \multirow{2}{*}{$\begin{array}{l}\text { Пасиви } \\
599396 \\
\end{array}$} & \multicolumn{2}{|c|}{$\begin{array}{l}\text { Зобов’язання, їх } \\
\text { частка в пасивах }\end{array}$} & \multicolumn{2}{|c|}{$\begin{array}{c}\text { Кошти клієнтів, } \\
\text { їх частка } \\
\text { в зобов'язаннях }\end{array}$} & \multicolumn{2}{|c|}{$\begin{array}{c}\text { Кошти юридичних } \\
\text { осіб, їх частка в } \\
\text { портфелі } \\
\end{array}$} & \multicolumn{2}{|c|}{$\begin{array}{c}\text { Кошти фізич- } \\
\text { них осіб, їх час- } \\
\text { тка в портфелі }\end{array}$} \\
\hline & & 529818 & $88,4 \%$ & 275477 & $52,0 \%$ & 111995 & $40,7 \%$ & 163482 & $59,3 \%$ \\
\hline $1.01 .2009 \mathrm{p}$. & 926086 & 806823 & $87,1 \%$ & 357147 & $44,3 \%$ & 143928 & $40,3 \%$ & 213219 & $59,7 \%$ \\
\hline $1.01 .2010 \mathrm{p}$ & 880302 & 765127 & $86,9 \%$ & 325210 & $42,5 \%$ & 115204 & $35,4 \%$ & 210006 & $64,6 \%$ \\
\hline $1.01 .2011 \mathrm{p}$ & 942088 & 804363 & $85,4 \%$ & 414771 & $51,6 \%$ & 144038 & $34,7 \%$ & 270733 & $65,3 \%$ \\
\hline 1.01.2012 p. & 1054280 & 898793 & & 492418 & & 186213 & & 306205 & $62,2 \%$ \\
\hline $1.01 .2013 \mathrm{p}$. & 1127192 & 957872 & $85,0 \%$ & 566553 & $59,1 \%$ & 202550 & $35,8 \%$ & 364003 & $64,2 \%$ \\
\hline $1.01 .2014 \mathrm{p}$ & 1278095 & 1085496 & $84,9 \%$ & 668674 & $61,6 \%$ & 234948 & $35,1 \%$ & 433726 & $64,9 \%$ \\
\hline $1.01 .2015 \mathrm{p}$ & 1316852 & 1168829 & $88,8 \%$ & 677743 & $58,0 \%$ & 261372 & $38,6 \%$ & 416371 & $61,4 \%$ \\
\hline $1.01 .2016 \mathrm{p}$ & 1254385 & 1150672 & $91,7 \%$ & 720705 & $62,6 \%$ & 318568 & $44,2 \%$ & 402137 & $55,8 \%$ \\
\hline $1.01 .2017 \mathrm{p}$ & 1256299 & 1132515 & $90,1 \%$ & 807065 & $71,3 \%$ & 369913 & $45,8 \%$ & 437152 & $54,2 \%$ \\
\hline $1.01 .2018 \mathrm{p}$. & 1282748 & 1112359 & $86,7 \%$ & 825822 & $74,2 \%$ & 370108 & $44,8 \%$ & 455714 & $55,2 \%$ \\
\hline $1.05 .2018 \mathrm{p}$ & 1308571 & 1149670 & $87,9 \%$ & 867583 & $75,5 \%$ & 385555 & $44,4 \%$ & 482028 & $55,6 \%$ \\
\hline
\end{tabular}

* складено автором за даними НБУ [8]

За даними НБУ видно, що за 2015 р. пасиви банків (валюта балансу) України значно скоротились. Зобов'язання 32015 р. мали тенденцію до скорочення до 1.05.2018 р., що пов'язано в першу чергу зі зменшенням кількості банків.

Обсяг депозитних коштів клієнтів та їх питома вага в зобов'язаннях мали тенденцію до зростання, окрім 2014 р., коли економіка зазнала найбільшого шоку та почалось масове банкрутство банків. Вже на 2.05 .2018 р. питома вага депозитної бази в зобов'язаннях досягла максимуму за останні десять років, склавши 75,5\%.

Якщо розглядати динаміку та структуру депозитів, то за період з 1.01.2008 р. по 1.05.2018 р. найбі- льшу питому вагу (55,6\% у структурі депозитного портфеля на кінець періоду) має частка депозитів фізичних осіб, які дорівнюють 482028 млн. грн. При цьому відчутною $є$ тенденція зростання коштів юридичних осіб.

Для банківських установ найбільш стабільним елементом депозитної бази є строкові депозити, але відбулось значне скорочення їх частки з 2014 р. 3 62,2\% до 49,3\% на кінець 2017 р. 3 початку 2018 р. спостерігається їх приріст до 50,5\%.

Однією з стійких проблем депозитного ринку $\epsilon$ незбалансована регіональна структура вкладів населення. Розподіл загальної суми банківських вкладів населення за регіонами наведено у табл. 2 .

Таблиця 2

Розподіл банківських вкладів населення за регіонами України*

\begin{tabular}{|l|c|c|c|c|}
\hline \multicolumn{1}{|c|}{ Область } & $\begin{array}{c}\text { Залишок вкладів } \\
\text { населення на } \\
01.08 .2018 \text { р., } \\
\text { млн. грн. }\end{array}$ & $\begin{array}{c}\text { Чисельність } \\
\text { населення на } \\
01.06 .2018 \mathrm{p.} .\end{array}$ & $\begin{array}{c}\text { Середня сума } \\
\text { депозиту на 1 } \\
\text { мешканця, } \\
\text { тис. грн. }\end{array}$ & $\begin{array}{c}\text { Частка об- } \\
\text { ласті у зага- } \\
\text { льній сумі } \\
\text { вкладів в } \\
\text { Україні, \% }\end{array}$ \\
\hline Київська та м. Київ & 181286 & 4694312 & 38,6 & 37,3 \\
\hline Дніпропетровська & 46100 & 3220688 & 14,3 & 9,5 \\
\hline Львівська & 31970 & 2524797 & 12,7 & 6,6 \\
\hline Одеська & 29724 & 2380896 & 12,5 & 6,1 \\
\hline Запорізька & 20288 & 1715991 & 11,8 & 4,2 \\
\hline Харківська & 27925 & 2684903 & 10,4 & 5,8 \\
\hline Полтавська & 13833 & 1408431 & 9,8 & 2,8 \\
\hline Черкаська & 9700 & 1214757 & 8,0 & 2,0 \\
\hline Херсонська & 7430 & 1043168 & 7,1 & 1,5 \\
\hline Сумська & 7751 & 1089142 & 7,1 & 1,6 \\
\hline Хмельницька & 8978 & 1270301 & 7,1 & 1,8 \\
\hline Миколаївська & 6977 & 1137127 & 7,1 & 1,7 \\
\hline Чернігівська & & 1014453 & 6,9 & 1,4 \\
\hline
\end{tabular}


Продовження табл.2

\begin{tabular}{|l|c|c|c|c|}
\hline \multicolumn{1}{|c|}{ Область } & $\begin{array}{c}\text { Залишок вкладів } \\
\text { населення на } \\
01.08 .2018 \text { р., } \\
\text { млн. грн. }\end{array}$ & $\begin{array}{c}\text { Чисельність } \\
\text { населення на } \\
01.06 .2018 \text { p. }\end{array}$ & $\begin{array}{c}\text { Середня сума } \\
\text { депозиту на 1 } \\
\text { мешканця, } \\
\text { тис. грн. }\end{array}$ & $\begin{array}{c}\text { Частка області } \\
\text { у загальній } \\
\text { сумі вкладів в } \\
\text { Україні, } \%\end{array}$ \\
\hline Волинська & 6808 & 1037118 & 6,6 & 1,4 \\
\hline Вінницька & 9999 & 1569491 & 6,4 & 2,1 \\
\hline Івано-Франківська & 8551 & 1375445 & 6,2 & 1,8 \\
\hline Житомирська & 7612 & 1226722 & 6,2 & 1,6 \\
\hline Кіровоградська & 5710 & 952177 & 6,0 & 1,2 \\
\hline Рівненська & 6857 & 1159361 & 5,9 & 1,4 \\
\hline Чернівецька & 5342 & 905517 & 5,9 & 1,1 \\
\hline Тернопільська & 6008 & 1049469 & 5,7 & 1,2 \\
\hline Донецька & 19321 & 4186788 & 4,6 & 4,0 \\
\hline Закарпатська & 5010 & 1256959 & 4,0 & 1,0 \\
\hline Луганська & 4407 & 2161598 & 2,0 & 0,9 \\
\hline Україна разом & $\mathbf{4 8 5 6 2 2}$ & $\mathbf{4 2 2 7 9 6 1 1}$ & $\mathbf{1 1 , 5}$ & $\mathbf{1 0 0 , 0}$ \\
\hline
\end{tabular}

* складено автором за даними НБУ [8]

Аналізуючи дані табл. 2 можна зробити висновки, що у Київській області зосереджено 37,3\% суми депозитів населення України, що робить цей регіон лідируючим по вкладах фізичних осіб, а також йому належать перші позиції по середній сумі депозиту на 1 мешканця (38,6 тис. грн). До лідерів за залученням вкладів населення також належать області, що мають найбільшу кількість населення та значний економічний потенціал, а саме: Дніпропетровська область - 9,5\% загальної суми вкладів населення України, Львівська - 6,6\%, Одеська - 6,1\%, Харківська - 5,8\%, Запорізька - 4,2\%, Донецька - 4,0\%. Найгірші позиції 3 точки зору розмірів депозитів посідають Луганська область - 2,0 тис. грн заощаджень на 1 особу, Закарпатська область - 4,0 тис. грн, Донецька область - 4,6 тис. грн, Тернопільська область - 5,7 тис. грн на 1 особу. Такі диспропорції у сфері залучення банківських ресурсів викликані об'єктивними обставинами та практично не змінювались в останні роки.

Аналіз банківських депозитів фізичних осіб за строками повернення показує, що вклади до 1 року найбільш популярний в Україні вид депозитів, що пояснюється, зокрема, змінами у законодавстві, які ще у 2015 р. розділили депозити на такі, що можуть бути достроково зняті, та строкові. Таким чином, вкладники втратили можливість дострокового припинення строкової депозитної угоди. Саме тому вкладники обирають переважно короткострокові (на 3, 6, 9, 12 місяців) вклади. Питома вага вкладів до 1 року змінювалась таким чином: станом на 01.01.2014 р. - 27\%, на 01.01 .2015 p. - 32\%, на 01.01.2016 p. - 43\%, на 01.01.2017 p. $-39 \%$, на 01.01 .2018 р. та 01.07 .2108 р. $37 \%$ [9].

Вклади до запитання (на вимогу) - це гроші, які можуть бути зняті з рахунків вкладниками у будьякий момент без попередження. Вони є нестабільними залишками на рахунках і тому не можуть бути джерелом для довгострокового кредитування реального сектору економіки. Досліджуючи динаміку цих депозитів в останні роки, можна стверджувати, що відбувається стабільне зростання частки залишків на вимогу у загальній сумі вкладів: на початок 2014 р. - 20\%, на початок 2015 р. - 24\%, на початок 2016 p.
- 27\%, на початок 2017 р. - 29\%, на початок 2018 р. $34 \%$, на середину 2018 р. - 38\%. Таким чином, у цей період спостерігаються негативні зміни у структурі банківських вкладів населення.

Стосовно довгострокових (на термін понад 2 роки) вкладів, які мають бути основним джерелом довгострокового кредитування в Україні, слід відзначити, що їх максимальна питома вага (3-4\% в останні роки) протягом 2016-2018 рр. впала до рівня 1\%, що перешкоджає розвитку економіки.

Скорочення банківських депозитів у період 2014-2017 pр. було викликано і девальвацією гривні у цей період, що привела до негативних наслідків у функціонуванні банківської системи і зростання недовіри населення до заощаджень у національній грошовій одиниці.

Висновки та перспективи подалыших досліджень. За результатами проведеного дослідження, до найважливіших напрямків відновлення та зростання депозитної бази комерційних банків в Україні слід віднести такі:

- забезпечення стабільності національної грошової одиниці (за рахунок валютної лібералізації 3 введенням в дію 37 лютого 2019 року Закону України «Про валюту і валютні операції»);

- стимулювання своєчасного повернення в Україну валютних коштів підприємств-експортерів;

- мінімізація темпів цінового зростання шляхом неухильного дотримання режиму інфляційного таргетування;

- стимулювання прямих іноземних інвестицій;

- рекапіталізація банківської системи шляхом приведення у відповідність нормативів капіталу банківської системи до вимог Базеля III;

- виведення з ринку хронічно збиткових банків;

- реформування державних банків 3 метою підвищення стандартів корпоративного управління, реалізація Комплексної стратегії розвитку державних банків, що передбачено «Комплексною програмою розвитку фінансового сектору України до 2020 року» [10];

- підвищення мінімальної суми гарантування вкладів фізичних осіб. 
Подальші дослідження будуть спрямовані на ристання ресурсів комерційних банків. проблеми забезпечення належної ефективності вико-

\section{Лiтература}

1. Врублевський О. С. Громадянин і банк: депозитні операції. К.: ТОВ «ІКЦ Леста», 2005. 44 с.

2. Кожель Н. О. Оцінка факторів впливу на процес формування та реалізації депозитної політики банку // Проблеми і перспективи розвитку банківської системи України : зб. наук. праць. 2005. № 12. С. 223 234. $215 \mathrm{c}$.

3. Лагутін В. Д. Кредитування: теорія і практика: навч. посібник. К.: Тов-во «Знання», КОО, 2002.

4. Орлюк О. П. Фінансове право: навч. посібник. К.: Юрінком Інтер, 2003. 528 с.

5. Про порядок здійснення банками України вкладних (депозитних) операцій з юридичними і фізичними особами: Постанова Правління Національного банку України від 03.12.2003 року № 516. [Електронний pecypc].URL: http://zakon3.rada.gov.ua/laws/show/z1256-03(дата звернення 10.02.2019)

6. Про банки і банківську діяльність: Закон України за станом на 09.02.2019. [Електронний ресурс]. URL: http://zakon3.rada.gov.ua/laws/show/2121-14 (дата звернення 15.02.2019)

7. Аналіз банківської діяльності: підручник / Герасимович А.М. та ін.; за ред. А. М. Герасимовича. К.: KHEУ, 2004. 599 c.

8. Основні показники діяльності банків України. Офіційне інтернет-представництво Національного Банку України. [Електронний ресурс]. URL: https://bank.gov.ua/control/uk/publish/article?art_id=34661442\&cat_id=34798593. (дата звернення 10.02.2019)

9. Основні проблеми та напрями відновлення депозитного ринку як ключової передумови економічного зростання в Україні. Аналітична записка. [Електронний ресурс]. URL: http://www.niss.gov.ua/articles/3173/ (дата звернення 10.02.2019)

10. Комплексна програма розвитку фінансового сектору України до 2020 року. [Електронний ресурс]. URL: https://bank.gov.ua/doccatalog/document?id=43352266 (дата звернення 10.02.2019)

Стаття надійшла 25.02.2019 Стаття прийнята до друку 11.03.2019 Доступно в мережі Internet 5.07.2019

Тарасова Е.В.

кандидат экономических наук, доцент кафедра учета и аудита

Одесская национальная академия пищевых технологий ул. Канатная, 112, г. Одесса, Украина, 65039

E-mail: tarasovaelenaonaft@gmail.com ORCID ID: 0000-0002-4372-3677

\section{ПРОБЛЕМЫ ФОРМИРОВАНИЯ ДЕПОЗИТНОЙ БАЗЫ КОММЕРЧЕСКИХ БАНКОВ УКРАИНЫ}

В статье исследуются проблемы формирования банковских ресурсов, восстановления и наращивания депозитной базы коммерческих банков, которая играет чрезвычайно важную роль в развитии экономики. Обоснована роль депозитного рынка в обеспечении стабильного экономического роста. Рассмотрена сущность депозитных операций и приведена классификация депозитов по различным признакам. Проанализированы тенденции в формировании депозитной базы коммерческих банков Украины и диспропорции в сфере привлечения банковских ресурсов.

В последние годы перед банковской системой Украины встал ряд проблем, основными из которых можно считать: сокращение вкладов населения, ухудшение качества кредитного портфеля, значительную девальвацию гривны, высокие темпы инфляции, убыточность большого количества банковских учреждений.

Основная часть ресурсов банков сформирована за счет депозитов клиентов. Одной из устойчивых проблем депозитного рынка Украины является несбалансированная региональная структура вкладов населения. Анализ банковских депозитов фризиеских лиц по срокам возврата показывает, что вклады до 1 года - наиболее популярный в Украине вид депозитов, что объясняется, в частности, изменениями в законодательстве, в связи с которыми вкладчики потеряли возможность досрочного прекращения срочного депозитного договора. Именно поэтому вкладчики выбирают преимущественно краткосрочные вклады, что препятствует развитию экономики.

Сформулированы задачи, решение которых позволит оптимизировать депозитную политику банков, вернуть доверие населения к банковским учреждениям и стимулировать к сбережениям.

Ключевые слова: депозит, депозитная операция, депозитная база, депозитная политика, сбережения, коммерческий банк, экономический рост. 


\author{
Tarasova 0. \\ Ph.D, Associate Professor \\ Department of Accounting and Auditing \\ Odessa National Academy of Food Technologies \\ st. Kanatna, 112, Odessa, Ukraine, 65039 \\ E-mail: tarasovaelenaonaft@gmail.com \\ ORCID ID: 0000-0002-4372-3677
}

\title{
THE PROBLEMS OF FORMATION OF THE DEPOSIT BASE OF COMMERCIAL BANKS OF UKRAINE
}

The article examines the problems of forming banking resources, restoring and increasing the deposit base of commercial banks, which plays an extremely important role in the development of the economy. The role of the deposit market in ensuring stable economic growth has been substantiated. The essence of deposit operations has been considered and the classification of deposits according to various criteria has been given. The trends in the formation of the deposit base of commercial banks of Ukraine and the imbalance in attracting banking resources have been analyzed.

In recent years, the banking system of Ukraine has faced a number of problems, the main of which can be considered: a reduction in public deposits, a deterioration in the quality of the loan portfolio, a significant devaluation of the $\mathrm{UAH}$, high inflation rates, a loss of a large number of banking institutions.

The main part of the resources of banks has been formed at the example of customers' deposits. One of the sustainable problems of the deposit market of Ukraine is the unbalanced regional structure of public deposits. The analysis of bank deposits of individuals by return periods shows that deposits up to 1 year are the most popular type of deposits in Ukraine, which is due, in particular, to changes in legislation in connection with which depositors have lost the possibility of early termination of a fixed-term deposit agreement. That is why investors choose mainly short-term deposits, which hinders the development of the economy.

The tasks, the solution of which will allow to optimize the deposit policy of banks, to return public confidence in banking institutions and to encourage savings have been formulated. nomic growth.

Keywords: deposit, deposit operation, deposit base, deposit policy, savings, commercial bank, eco-

\section{References}

1. Vrublevskyi, O. S. (2005). Hromadianyn i bank: Depozytni operatsii. Kyiv: TOV «IKTs Lesta».

2. Kozhel, N. O. (2005). Otsinka faktoriv vplyvu na protses formuvannia ta realizatsii depozytnoi polityky banku. Problemy I Perspektyvy Rozvytku Bankivskoi Systemy Ukrainy, (12), 223-234.

3. Lahutin, V. D. (2002). Kredytuvannia : Teoriia i praktyka. Kyiv: Tov-vo «Znannia», KOO.

4. Orliuk, O. P. (2003). Finansove pravo. Kyiv: Yurinkom Inter.

5. Pro poriadok zdiisnennia bankamy Ukrainy vkladnykh (depozytnykh) operatsii z yurydychnymy i fizychnymy osobamy: Postanova Pravlinnia Natsionalnoho banku Ukrainy vid 03.12.2003 roku № 516. (2019). Retrieved February 10, 2019, from http://zakon3.rada.gov.ua/laws/show/z1256-03

6. Pro banky i bankivsku diialnist: Zakon Ukrainy za stanom na 09.02.2019. (2019). Retrieved February 15, 2019, from http://zakon3.rada.gov.ua/laws/show/2121-14

7. Herasymovych, A. M. (2004). Analiz bankivskoi diialnosti (A. M. Herasymovych, Ed.). Kyiv: KNEU.

8. Osnovni pokaznyky diialnosti bankiv Ukrainy. Ofitsiine internet-predstavnytstvo Natsionalnoho Banku $\begin{array}{llllll}\text { Ukrainy. } & \text { (2019). } & \text { Retrieved } & \text { February } & 10, & \text { 2019, }\end{array}$ https://bank.gov.ua/control/uk/publish/article?art_id=34661442\&cat_id=34798593

9. Osnovni problemy ta napriamy vidnovlennia depozytnoho rynku yak kliuchovoi peredumovy ekonomichnoho zrostannia v Ukraini. Analitychna zapyska. (2018). Retrieved February 10, 2019, from http://od.niss.gov.ua/articles/3173/

10. Kompleksna prohrama rozvytku finansovoho sektoru Ukrainy do 2020 roku. (2017). Retrieved February 10, 2019, from https://bank.gov.ua/doccatalog/document?id=43352266

Received 25 February 2019

Approved 11 March 2019

Available in Internet 5.07.2019

Цитування згідно ДСТУ 8302:2015

Тарасова О.В. Проблеми формування депозитної бази комерційних банків України // Економіка харчової промисловості. 2019. Т. 11, Вип. 2. С. 89-94. doi: 10.15673/fie.v11i2.1400

Cite as APA style citation

Tarasova O. (2019). The problems of formation of the deposit base of commercial banks of Ukraine. Food Industry Economics,

11(2), 89-94. doi: 10.15673/fie.v11i2.1400 